\title{
Peculiarities of Functional Activity of the Pituitary-Thyroid System in Adolescents of the North
}

\author{
Tatyana E. Burtseva, PhD, ScD ${ }^{1,2^{*}}$; Margarita I. Samsonova, $\mathrm{PhD}, \mathrm{ScD}^{3}$; Sardana A. \\ Evseeva $^{2}$; Maya S. Savvina, $\mathrm{PhD}^{2}$; Vyacheslav G. Chasnyk, $\mathrm{PhD}, \mathrm{ScD}^{4}$ \\ ${ }^{\prime}$ M. K. Ammosov North-Eastern Federal University, Yakutsk, Russia \\ ${ }^{2}$ Yakut Science Center of Complex Medical Problems, Yakutsk, Russia \\ ${ }^{3}$ Children's Hospital, Yakutsk, Russia \\ ${ }^{4}$ Saint Petersburg State Pediatric Medical University, St. Petersburg, Russia
}

\begin{abstract}
The article presents a pilot study on the assessment of functional activity of pituitary-thyroid system (PTS) in adolescents as a factor of long-term adaptation to life in the North. The study included 864 adolescents of different ethnic groups (the Russians, the Yakuts, the Evenks, the Evens, the Dolgans, the Chukchi, the Yukagir) and found that PTS functional activity varies according to ethnicity.(International Journal of Biomedicine. 2018;8(2):147-149.)
\end{abstract}

Key Words: adolescents • pituitary-thyroid system • Yakutia • ethnicity

\section{Abbreviations}

FT4, free thyroxine; FT3, free triiodothyronine; PTS, pituitary-thyroid system; SIPN, small indigenous people of the North; TSH, thyroid-stimulating hormone; T3, total triiodothyronine.

\section{Introduction}

In the regions of Siberia, the North and the Far East of Russia, the pathology of the thyroid gland is one of the most common. In general, the prevalence of endocrine pathology among adolescents in these regions is 5 times higher than among the population of Russia as a whole. ${ }^{(1-5)}$ Yakutia belongs to the regions with endemic iodine deficiency. In a number of districts of Yakutia, the level of ioduria is about $26 \mu \mathrm{g} / \mathrm{l}$ vs. $100-200 \mu \mathrm{g} / \mathrm{l}$ in the norm.

The endocrine system indirectly affects the processes of adaptation to various endo- and exogenetic factors, especially during the period of physical and sexual maturation. ${ }^{(6,7)}$ Hormonal changes are of great importance in the development of various deviations in the state of children's health. ${ }^{(8)}$ The

*Corresponding author: Tatiana E. Burtseva, PhD, ScD. M.K. Ammosov North-Eastern Federal University, Yakutsk, Russia. E-mail: $\underline{\text { bourtsevat@yandex.ru }}$ complex interrelations of neuro-humoral mechanisms and their dynamic functional restructuring in response to the influence of the internal and external environment require a comprehensive study and objective evaluation of the hormonal profile of children. ${ }^{(2,7,9)}$

\section{Materials and Methods}

This research was carried out within the framework of the project "Monitoring the state of children's health" (registration number 0120-128-07-99). The study was approved by the Ethics Committee of the Yakut Science Center of Complex Medical Problems. Written informed consent was obtained from the parents /legal guardians.

We examined the health status of 864 adolescents of different ethnic groups living in 5 settlements in the Far North of Yakutia (Table 1). Hormones of PTS-TSH, T3, FT4, and FT3 - have been determined by enzyme immunoassay ("Victor-2" analyzer) in adolescents of health group I-II using appropriate test systems: Monobind (USA), Xema (Russia). 
Table 1.

Prevalence of endocrine pathology in adolescents of Yakutia

\begin{tabular}{|l|c|c|}
\hline \multicolumn{1}{|c|}{ Settlement } & $\begin{array}{c}\text { Identified } \\
\text { endocrine } \\
\text { pathology }\end{array}$ & $\begin{array}{c}\text { Prevalence of } \\
\text { endemic goiter }\end{array}$ \\
\hline Berezovka (Srednekolimsky) & $39(27.5 \%)$ & $8(5.6 \%)$ \\
\hline Olenegorsk (Alaihovsky) & $23(29.5 \%)$ & $16(20.5 \%)$ \\
\hline Andryushkino(Nizhnekolimsky) & $126(44.2 \%)$ & $22(8.0 \%)$ \\
\hline Saylyk (Ust-Yansky) & $82(36.8 \%)$ & $36(16.1 \%)$ \\
\hline Total & $270(37.6 \%)$ & $82(11.4 \%)$ \\
\hline
\end{tabular}

Statistical analysis was performed using StatSoft Statistica v6.0. Baseline characteristics were summarized as frequencies and percentages for categorical variables and as mean \pm SEM for continuous variables. Multiple comparisons were performed with one-way ANOVA and Tukey's HSD test. A probability value of $\mathrm{P}<0.05$ was considered statistically significant.

\section{Results}

In adolescents older than 15 years, the prevalence of endocrine pathology was higher than in those 10-14 years of age. The prevalence of endemic goiter depended on the place of residence. In the Saylyk and Olnegorsk settlements, in adolescent over the age of 15, endemic goiter was registered in $16.1 \%$ and $20.5 \%$ of cases, respectively.

These data are higher than in the children of the Far Eastern District, previously described by V.Kozlov. ${ }^{(10)}$
Table 2.

The levels of PTS hormones in general groups of teenagers in Yakutia

\begin{tabular}{|c|c|c|c|c|}
\hline Population & $\begin{array}{c}\text { TSH } \\
\mu \mathrm{U} / \mathrm{mL}\end{array}$ & $\begin{array}{c}\mathrm{T} 3 \\
\mathrm{nmol} / \mathrm{L}\end{array}$ & $\begin{array}{c}\text { FT4 } \\
\mathrm{pmol} / \mathrm{L}\end{array}$ & $\underset{\mathrm{pmol} / \mathrm{L}}{\mathrm{FT}_{3}}$ \\
\hline All teenagers & $\begin{array}{c}(\mathrm{n}=864) \\
1.76 \pm 0.04\end{array}$ & $\begin{array}{c}(\mathrm{n}=390) \\
3.04 \pm 0.04\end{array}$ & $\begin{array}{c}(\mathrm{n}=401) \\
14.6 \pm 0.15\end{array}$ & $\begin{array}{c}(\mathrm{n}=403) \\
2.26 \pm 0.04\end{array}$ \\
\hline All girls & $\begin{array}{c}(\mathrm{n}=385) \\
1.73 \pm 0.06\end{array}$ & $\begin{array}{c}(\mathrm{n}=175) \\
2.88 \pm 0.07\end{array}$ & $\begin{array}{c}(\mathrm{n}=166) \\
14.7 \pm 0.25\end{array}$ & $\begin{array}{c}(\mathrm{n}=166) \\
2.07 \pm 0.05\end{array}$ \\
\hline All boys & $\begin{array}{c}(n=479) \\
1.78 \pm 0.06\end{array}$ & $\begin{array}{c}(n=215) \\
3.16 \pm 0.06\end{array}$ & $\begin{array}{c}(n=235) \\
14.5 \pm 0.19\end{array}$ & $\begin{array}{c}(n=237) \\
2.39 \pm 0.07\end{array}$ \\
\hline All Caucasoids & $\begin{array}{c}(\mathrm{n}=126) \\
1.47 \pm 0.08\end{array}$ & $\begin{array}{c}(\mathrm{n}=85) \\
3.14 \pm 0.07\end{array}$ & $\begin{array}{c}(\mathrm{n}=39) \\
15.1 \pm 0.56\end{array}$ & $\begin{array}{c}(\mathrm{n}=39) \\
2.52 \pm 0.13\end{array}$ \\
\hline All indigenous & $\begin{array}{c}(\mathrm{n}=818) \\
1.65 \pm 0.04\end{array}$ & $\begin{array}{c}(\mathrm{n}=352) \\
3.19 \pm 0.07\end{array}$ & $\begin{array}{c}(\mathrm{n}=395) \\
14.6 \pm 0.15\end{array}$ & $\begin{array}{c}(\mathrm{n}=397) \\
2.26 \pm 0.05\end{array}$ \\
\hline
\end{tabular}

$*_{-} P<0.05$ between the indigenous and non-indigenous groups of adolescents

The levels of PTS hormones in general groups of teenagers in Yakutia are presented in Table 2. The data obtained indicate that TSH secretion was significantly different between the indigenous and non-indigenous groups of adolescents.

The analysis of the hormone levels by ethnicity showed no gender differences, except for Dolgan teenagers (Table 3).

Taking into account the age of the examined adolescents, significant differences in TSH levels were found in the Evens;

Table 3.

The levels of PTS hormones in adolescents of different ethnic groups of Yakutia

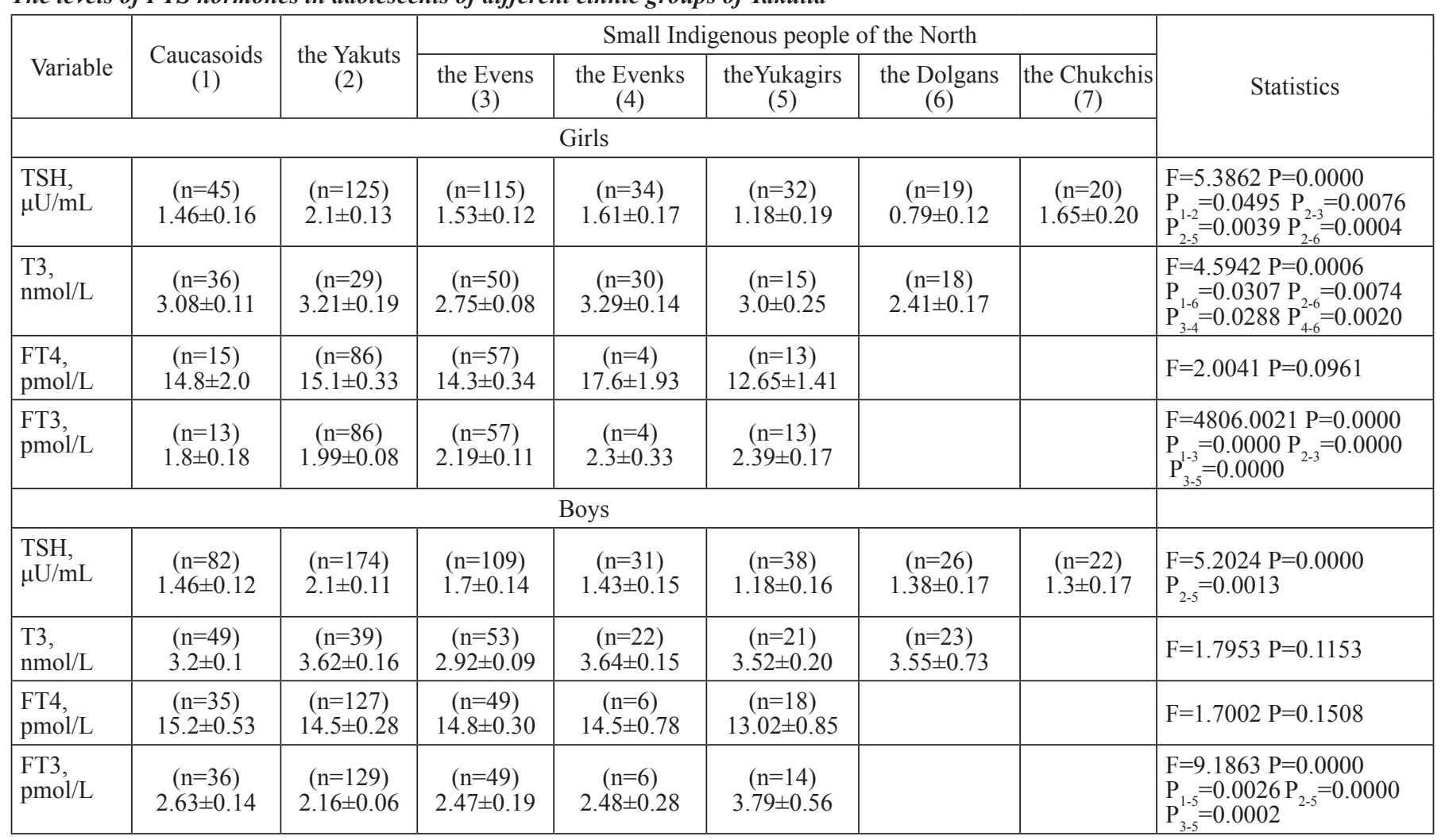


and in the pubertal period, in comparison with the prepubertal period, these levels increased in girls and decreased in boys. Gender differences for T3, as well as for TSH, were obtained only for the Dolgans. Statistically significant age-related differences were found in Yakut girls.

There were gender differences in the FT3 level in Caucasoids and Yukagirs $(P<0.05)$, but age-related differences for this hormone were not noted. There were no gender differences in the FT4 level in the general groups of the examined adolescents, and age-related differences were obtained only in Caucasians. In the general groups of Caucasians, in comparison with the indigenous adolescents (the Yakuts and SIPN), we revealed statistically significant differences only for TSH. There were no statistically significant differences in all studied hormones in adolescents of both sexes between indigenous and non-indigenous adolescents. Gender differences were obtained only for FT3 in Caucasoids.

In adolescents of the indigenous population, depending on ethnicity, comparative analysis showed that the thyrotropic function of the pituitary gland in SIPN adolescents was statistically lower $(P<0.05)$ than in the Yakuts, but the blood content of the most active fraction of thyroid hormones (FT3) in Yakut adolescents showed a statistically significant decrease $(P<0.05)$. The gender differences in the content of PTS hormones in adolescents of Caucasoids, Yakuts and SIPN showed that the Yakut girls had the highest thyroid-stimulating function of the pituitary gland in comparison with the girls of Caucasoids and SIPN $(P<0.05)$. In Yakut girls, the T3 level was also statistically higher than in SIPN girls, but the FT3 level was lower in comparison with this group $(P<0.05)$. The same tendency was observed in boys.

In conclusion, the results obtained are consistent with the high level of endemic thyroid disease in Yakutia. The study found that the functional activity of the endocrine system in adolescents in Yakutia varies according to their ethnicity.

\section{Competing interests}

The authors declare that they have no competing interests.

\section{Sources of Funding}

This study was funded by RFBR according to the research project \#18-05-60035_Arctica.

\section{References}

1. Danilova GI. Endemic goiter in children of the Republic of Sakha (Yakutia). Abstract of PhD Thesis. M.; 1999. [In Russian]. 2. Selyatitskaya VG, Pal'chikova NA, Kuz'minova OI, Novoselova TI. [The study of the provision of the body with iodine and the assessment of hormonal status in the risk group for thyroid diseases among employees of industrial enterprises in the city of Mirny]. Proceedings of the All-Russia scientific conference «North-man: problems of health preservation.» Krasnoyarsk; 2001:217-219. [In Russian].

3. Savchenkov MF, Selyatitskaya VG, Kolesnikov SI, Bashirova GI, Brovina FY, Zacharenko RV, et al. Iodine and health of the population of Siberia. Novosibirsk: Nauka; 2002. 4. Zakharenko RV, P'yankova YeYu, Luz'yanina GA, Sirotina BZ. [Iodine deficiency disorders in the Khabarovsk Territory: the incidence of goitre among schoolchildren in Khabarovsk and Komsomolsk-on-Amur]. Proceedings of the scientific conference "A teenager at the turn of the century." Khabarovsk; 2001:12-13. [In Russian].

5. Stroyev YU, Churilov LP. Endocrinology of adolescents. In: Zaychik ASh, editor. SPb. : ELBI-SPb; 2004. [In Russian]. 6. Kaznacheyev VP. Essays on the theory and practice of human ecology. M.: Nauka; 1983. [In Russian].

7. Minin VV. Features of vegetative and endocrine functions of urban and rural schoolchildren of pubertal age. Abstract of PhD Thesis. Novosibirsk; 2000. [In Russian].

8. Domin VF. [The importance of unfavorable environmental factors in the formation of children's pathology]. Pediatriia. 1995;(3):98-101. [Article in Russian].

9. Anderson GM, Connors JM, Hardy SL, Valent M, Goodman RL. Thyroid hormones mediate steroid-independent seasonal changes in luteinizing hormone pulsatility in the ewe. Biol Reprod. 2002;66(3):701-6.

10. Kozlov VK. Health of children and adolescents in the Far East. Novosibirsk: SB RAMS;2003. [In Russian]. 